\title{
Excystment of the oligotrich ciliate Strombidium conicum
}

\author{
Young-Ok Kim, Akira Taniguchi
}

Laboratory of Biological Oceanography, Faculty of Agriculture, Tohoku University, Aoba-ku, Sendai 981, Japan

\begin{abstract}
Cysts of an oligotrich ciliate were isolated from sediment samples collected in Onagawa Bay on the northeastern Pacific coast of Japan and incubated under laboratory culture conditions. Successful excystment occurred regularly and the excysted cells were identified as Strombidium conicum. The cyst of $S$. conicum has a papulifères form and is enveloped by a double-layered wall, rigid inner and membranous outer layers. The excysted cells showed a distinctive conical shape with welldeveloped trichites and a ventral kinety restricted to the posterior end. The effects on excystment of temperature, light intensity, oxygen concentration, bacteria, and storage in the dark and at cold temperatures are reported. Among these variables, temperature is likely to be the principal factor controlling excystment.
\end{abstract}

KEY WORDS: Cyst · Excystment $\cdot$ Planktonic ciliate $\cdot$ Strombidium conicum

\section{INTRODUCTION}

Cyst formation by free-living protozoa, including planktonic forms, is well known as a common strategy in their life cycle (Corliss \& Esser 1974). Especially in the case of neritic temperate and boreal plankton, a resting stage is the primary strategy for survival in a seasonally variable environment (Smayda 1958). The resting stages of neritic plankton such as diatoms, dinoflagellates, cladocerans and copepods (cf. Fryxell 1983, Steidinger \& Walker 1984) have often been described. On the other hand, descriptions of the resting stages of planktonic ciliates, which are a major component in marine microbial food webs, are very rare.

Encystment of tintinnid ciliates, which occurs in the lorica, is now recognized as a regular event in the life cycle of neritic forms (Biernacka 1952, Reid \& John 1978, Paranjape 1980, Kamiyama \& Aizawa 1990, 1992). This suggests that this is also the case for the closely related non-loricate planktonic oligotrich ciliates. However, there is little direct evidence (cf. Reid \& John 1983). The taxonomic affinity of tintinnid cysts is clear as they are present in the lorica, however cysts of non-loricate oligotrichs cannot be convincingly classified unless the cells excyst.

Fauré-Fremiet (1948) reported that the ciliate Strombidium oculatum, which inhabits intertidal pools, swims freely in the water at low tide but sinks to the bottom and encysts at high tide. A recent study by Jonsson (1994) gave more detailed interpretation of the survival strategy of $S$. oculatum. He suggested that the encystment and excystment cycle of $S$. oculatum is synchronized with the tidal cycle and that this synchronization is a mechanism evolved by natural selection for increased residence time in tide pools. Reid (1987) reported mass encystment of another oligotrich, which was identified provisionally as Strombidium crassulum; his results were indirect as the increasing cyst density followed a decrease in motile forms of $S$. crassulum.

In this study we assessed excystment in the planktonic oligotrich ciliate Strombidium conicum by laboratory incubation of naturally occurring cysts in neritic sediment. The effects of different environmental parameters such as temperature, light intensity, dissolved oxygen, bacteria, and storage in the dark and at cold temperatures on the induction of excystment were also tested.

\section{MATERIALS AND METHODS}

Sampling of cysts. From May 1992 to July 1993, sediment samples were collected almost monthly using a 
Smith-McIntyre grab sampler at a station (depth $22 \mathrm{~m}$ ) in the innermost part of Onagawa Bay $\left(38^{\circ} 26.30^{\prime} \mathrm{N}\right.$, $141^{\circ} 27.70^{\prime} \mathrm{E}$ ), on the northeastern Pacific coast of Japan.

Isolation of cysts. The upper $1 \mathrm{~cm}$ of 3 cores, which were subsampled from the sediment collected by a Smith-McIntyre sampler, was taken into a screw-capped plastic vessel and stored at $5^{\circ} \mathrm{C}$ in the dark. Sorting of the cysts was mainly done by following the method for dinoflagellate cysts (Matsuoka et al. 1989): $1 \mathrm{~g}$ (wet weight) of sediment was transferred to ca $100 \mathrm{ml}$ of filtered sea water and sonicated for $30 \mathrm{~s}$. The suspension was serially sieved through 125 and $20 \mu \mathrm{m}$ meshes. Residue on the $20 \mu \mathrm{m}$ sieve was resuspended in $10 \mathrm{ml}$ of filtered sea water to separate it from sand grains by panning on a watch glass. One $\mathrm{ml}$ of the supernatant containing the cysts was placed on a Sedgwick-Rafter chamber and cysts were sorted by micropipetting using a capillary pipette (50 to $150 \mu \mathrm{m}$ diam.) under an inverted microscope. The whole procedure used cooled ( 5 to $8^{\circ} \mathrm{C}$ ) filtered sea water to prevent maturation or excystment of the cysts before experimental treatment.

Culture of cysts. The sorted cysts were quickly washed twice in sterile filtered sea water and then inoculated one by one into wells of several sterile tissue culture plates (Corning Cell Wells No. 25860), which were filled with the same filtered water and placed on a coolant bag to prevent excystment during the sorting. After inoculation the plates were treated in one of the following ways: (1) to determine the effects of temperature and light, the plates were incubated at 10,15 and $20^{\circ} \mathrm{C}$ in the dark or in light of approximately $14 \mu \mathrm{E} \mathrm{m}^{-2} \mathrm{~s}^{-1}$ cool-white illumination with a $12 \mathrm{~h}$ light, $12 \mathrm{~h}$ dark photocycle; (2) the effect of lowered dissolved oxygen concentration was checked by exposing the plates in a plastic bag filled with nitrogen gas for $24 \mathrm{~h}$ and then sealing the plates tightly with a lid, which lowered and kept the oxygen concentration below ca 2 to $4 \mathrm{ml} \mathrm{l}^{-1}$ during the second series of incubations; (3) to determine the effect of bacteria, cysts were pretreated for $24 \mathrm{~h}$ in an antibiotic penicillinstreptomycin mixture $(0.02 \mathrm{ml}$ antibiotic mixture in $1 \mathrm{ml}$ filtered sea water) (Hoshaw \& Rosowski 1973) or an extract of Escherichia coli, which was prepared by a freeze-thawing-sonication method (Hughes et al. 1971); (4) the effect of winter condition was checked by storing the cysts in the dark and cold $\left(4^{\circ} \mathrm{C}\right)$ conditions for 1 to $8 \mathrm{mo}$. All of the cysts previously treated by (2), (3) \& (4) were then transferred to and incubated under warm and light conditions of $20^{\circ} \mathrm{C}$ and light of $14 \mu \mathrm{E}$ $\mathrm{m}^{-2} \mathrm{~s}^{-1}$ During the following 2 or $3 \mathrm{wk}$, excystment of individual cysts was recorded daily under an inverted microscope. The condition of the cysts that did not excyst within 3 wk was checked at longer (ca 5 d) intervals.

To sort and wash a sufficient number of cysts for treatment is time-consuming, especially when cysts are not abundant in the sediment samples. We sorted 10 cysts $\mathrm{h}^{-1}$ on average. A serious problem is the effect of the long sorting time on excystment. After observing a change in excystment due to the extended sorting time, we subsequently completed sorting within $1 \mathrm{~d}$ except in June, when preparation of 6 plates took a total of $3 \mathrm{~d}$. Therefore, we were not able to prepare enough plates to perform each experiment in replicate, and our conclusions may be weakened by the lack of replication. All 90 wells of a plate were never filled: the number of cysts inoculated for each treatment is given in Figs. 14 to 17.

Identification of cysts. Every excysted cell was micropipetted daily with a plastic capillary, fixed individually with Bouin's fluid $5 \%$ and then identified by the protargol staining method (quantitative protargol stain, QPS; Montagnes \& Lynn 1987). The identification and photomicrography of the stained specimens were performed under an Olympus BH-2 microscope.

Morphology of the cysts was also examined in detail after fixation with $5 \%$ buffered formalin. The fixed cysts were thoroughly rinsed in distilled water. Some of them were mounted in glycerin jelly for light microscopic (LM) examinations and the others were treated by an alcohol dehydration, critical point drying, and coating with gold for scanning electron microscopic (SEM) examination (Hitachi S-700).

\section{RESULTS}

\section{Morphological features}

\section{Characteristic morphology of the cysts}

The cysts were characterized by a distinctive elliptical shape with a protrusion (Fig. 1) at one end marking the site of an excystment aperture (Figs. 2 \& 3), which was closed by a hyaline plug or papulla. The cysts with this shape have been termed 'papulifères'. a grouping of flask-shaped cysts (Reid \& John 1978). The papulifère cyst of Strombidium conicum was enveloped by 2 layers (Figs. $5 \& 6$ ); a thin outer layer was set off some distance from a thicker inner layer. The inner layer (endocyst) appeared to be a single rigid wall but the outer layer (ectocyst) was a fragile membranous coat with mucus. Sometimes foreign particles were heavily attached on the outer layer. When the cyst was treated in $1 \mathrm{~N} \mathrm{HCl}$, the inner rigid wall showed strong resistance, but the outer membranous layer was dissolved. In the raw sediment 

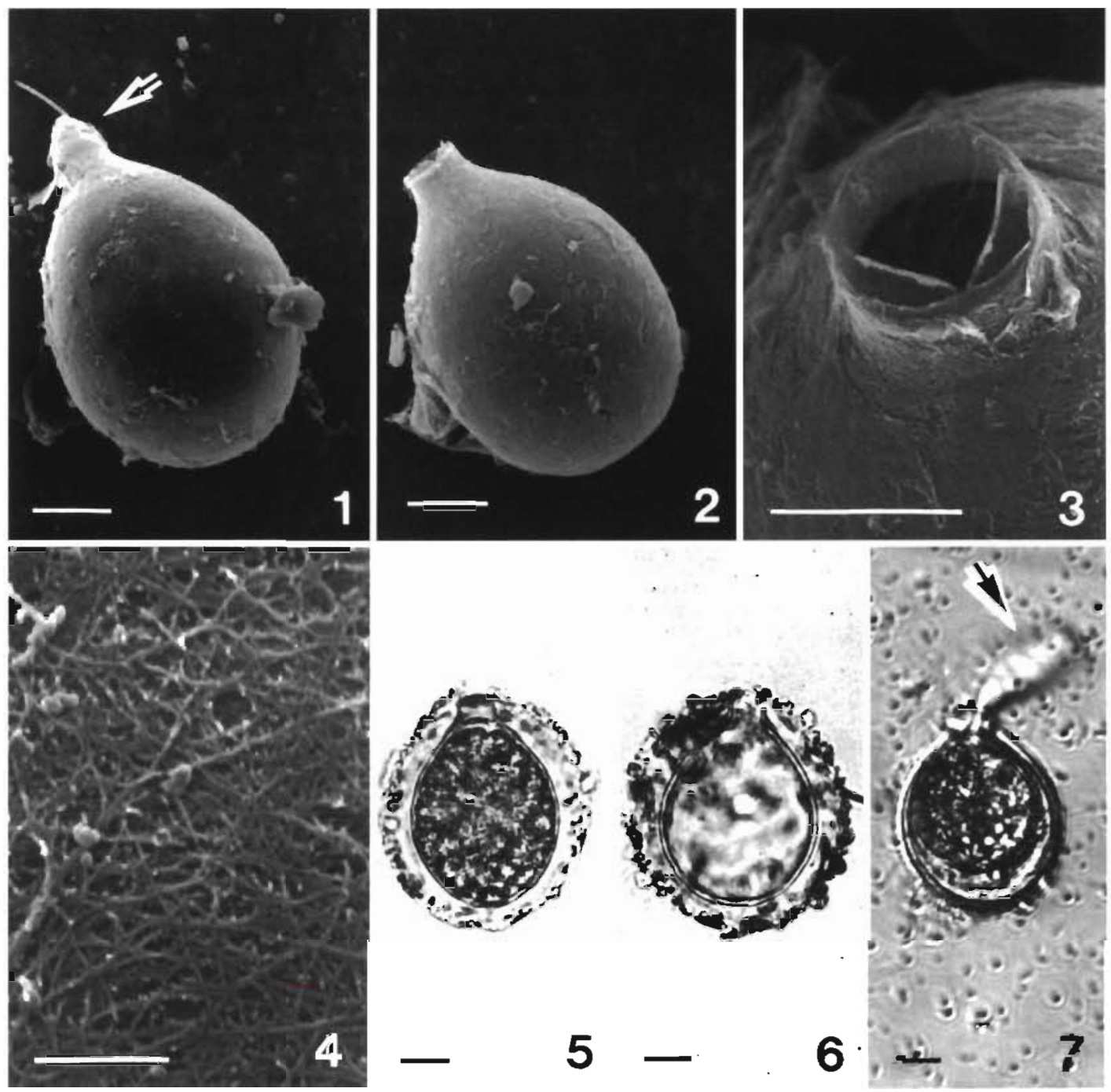

Figs. 1 to 7. Strombidium conicum. Characteristic features of cysts. Fig. 1. Cyst with a closed papulla (arrow). Fig. 2. Excysted cyst with a opened papulla. Fig. 3. Opened papulla showing a ruptured hyaline plug. Fig. 4. Surface of the inner wall showing a network of fine fibers. Figs. $5 \& 6$. Natural and excysted cysts covered by 2 layers, i.e. endocyst and extocyst. Fig. 7 . Emergence by cytoplasmic streaming (arrow) during the excystment. Figs 1 to 4 were microphotographed by SEM, Figs. 5 to 7 by LM. Scale bars $=10 \mu \mathrm{m}$, except Fig. $4(1 \mu \mathrm{m})$

sample, cysts without an outer layer were frequently observed.

Using SEM, the outer surface of the inner wall, which appears to be smooth under the light microscope, revealed a network of fine fibers (Fig. 4). Unfortunately, the outer membranous layer was easily lost during the preparation process for SEM observations. By observing excysted cysts, it was assumed that the aperture is formed by rupturing of the hyaline plug (Fig. 3).

The sizes of 50 cysts (mean \pm SD) were determined; the inner wall was $56 \pm 4.2 \mu \mathrm{m}$ in length and $42 \pm 2.4$ $\mu \mathrm{m}$ in width, and the outer layer was $63 \pm 4.4 \mu \mathrm{m}$ in length and $52 \pm 3.8 \mu \mathrm{m}$ in width.

\section{Cyst development during excystment}

A thick inner wall enclosed the dense granular cytoplasm (Fig. 5). The cytoplasm became gradually transparent and coarser during the course of excystment, and then an active cyclosis of the cytoplasm appeared just before the excystment. To penetrate the hyaline plug an intensive attack by ciliary beating was observed on the antero-internal end of the cyst. When the plug was opened a bud-like soft body emerged from the aperture (Fig. 7). The entire excystment process from cytoplasmic cyclosis within the cyst to the birth of a vegetative cell took about $24 \mathrm{~h}$. 


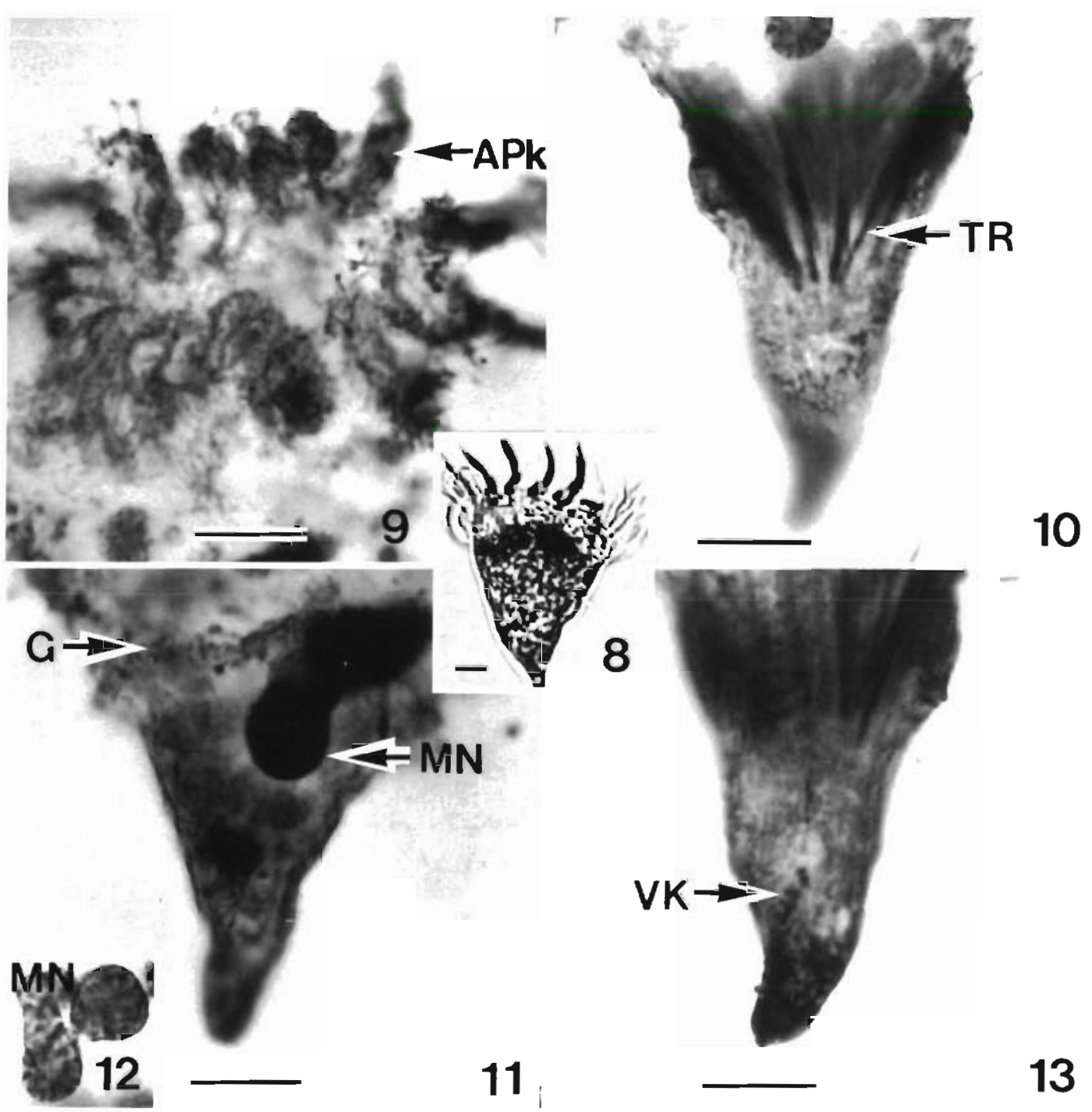

Figs. 8 to 13. Strombidium conicum. Characteristic features of an excysted cell. Fig. 8 . Conical body in living state: 65 to $75 \mu m$ in length and 30 to $35 \mathrm{\mu m}$ in width. Fig. 9. Detail of anterior part showing polykinetids (APk). Fig. 10. Detail of trichites (TR). Fig. 11. Detail of posterior part showing girdle $(G)$ and macronucleus (MN), Fig. 12. Irregular shape of a single macronucleus which seems to be divided into 2 parts. Fig. 13. Detail of ventral kinety (VK) in dorsal view (seen through the cell). Scale bars $=10 \mu \mathrm{m}$

\section{Description of excysted cell}

Referring to the taxonomic description by Montagnes et al. (1988), we identified the excysted cell as Strombidium conicum (Figs. 8 to 13). The conical body length and width were 60 to $63 \mu \mathrm{m}$ and 30 to $32 \mu \mathrm{m}$ for QPS cells ( $\mathrm{n}=3$ ), and 65 to $75 \mu \mathrm{m}$ and 30 to $35 \mu \mathrm{m}$ for living but inactive cells $(n=5)$. This indicates that shrink of cells due to QPS is about 10 to $20 \%$ of live volume. The anterior polykinetid zone (APZ) consisted of 16 polykinetids, although the ventral polykinetid zone (VPZ) could not be clearly observed due to the bursting of the anterior region of the fixed cells in Bouin's solution. The girdle (G), a supraequatorial ring of monokinetids with short stubby cilia, completely surrounded the cell. The ventral kinety of ca 15 ciliated monokinetids was restricted to the posterior end. Numerous trichites are inserted anterior to the girdle and extend postero-internally into the cell. The macronucleus was single and of a highly variable shape, being constricted into 2 or 3 parts as described by Montagnes et al. (1988).

\section{Effects of cultural conditions on excystment}

While the culture experiments were done without replication, the data obtained suggest the following gross trends of excystment of Strombidium conicum. 
Temperature and light

Excystment of the cysts sampled in winter (December 1992) was examined at 10 , 15 and $20^{\circ} \mathrm{C}$ in both light and dark. The rate of excystment at $15^{\circ} \mathrm{C}$ in light was higher for $4 \mathrm{~d}$ than at 10 and $20^{\circ} \mathrm{C}$ in light. The rate appeared much higher in light than in dark at every experimental temperature (Fig. 14a). The lowest rate of excystment was observed at $10^{\circ} \mathrm{C}$ in the dark. Similarly, cysts taken in spring (June 1992) also showed the highest rate at $15^{\circ} \mathrm{C}$ in light (Fig. 14b).

\section{Dissolved oxygen}

The effect of lowered oxygen concentration on excystment was examined for the cysts sampled in January 1993 (Fig. 15a). The excystment was slightly inhibited in low oxygen water (ca $4 \mathrm{ml} \mathrm{O}_{2} \mathrm{l}^{-1}$ ). Compared to the excystment rate in controls (ca $10 \mathrm{ml} \mathrm{O}_{2} \mathrm{l}^{-1}$ ), the rate was slightly lower in the low oxygen condition. The cysts sampled in February 1993 also revealed a much lower excystment rate in reduced oxygen conditions ( $\mathrm{ca} 2 \mathrm{ml} \mathrm{O}_{2} \mathrm{l}^{-1}$ ) (Fig. 15b). Recovery of excystment ability after re-transference from low oxygen to normal oxygen conditions was not examined in this work.

\section{Antibiotics and bacteria}

To investigate the effect of bacteria on excystment the cysts were pretreated in antibiotic mixture. The pretreatment appeared to inhibit the excystment of Strombidium conicum, i.e. the rate of excystment tended to decrease after antibiotic treatment (Fig. 15a, b). In additional experiments, the effect of a bacterial extract on the excystment rate was examined (Fig. 16). The treatment with the extract of Escherichia coli added showed a higher excystment rate than the control.

\section{Treatment in low temperature}

We have examined the effect of dark and cold conditions on the excystment of spring (June) and fall (October) cysts. After storage for 4 and 8 mo in the dark at $4^{\circ} \mathrm{C}$, the spring cysts showed a higher rate of excyst- ment than the control, which was tested within $1 \mathrm{wk}$ after sampling (Fig. 17a). The rate was higher for those cysts stored for 8 mo than for those stored for 4 mo. Conversely the fall cysts showed a delay of excystment after being stored in simulated winter conditions (Fig. 17b). Most cysts in the control and after 1 mo storage were excysted within 3 or $4 \mathrm{~d}$ but storage for more than 2 mo reduced and delayed excystment. After 6 mo storage only a few cysts were excysted.

\section{DISCUSSION}

Cysts of heterotrich, tintinnid, and oligotrich ciliates have been described as papulifères or flask-shaped cysts, which suggests their phylogenetic origin is different from hypotrich ciliates that produce simple spherical cysts (Reid \& John 1983). We have found papulifères belonging to Strombidium conicum and 
some other oligotrich and tintinnid species in Onagawa Bay. Along with the papulifères, stomatocysts (often called statospores) of Chrysophyceae were also found. Since the latter have a similar shape to the papulifères (a single exit pore closed by a pectic plug; Sandgren 1983, 1989), it is difficult to distinguish these by outer morphological features. However, chrysophyte statospores have a siliceous wall and are much smaller $(<20 \mu \mathrm{m})$ than most oligotrich cysts, so that both can be practically separated by sieving the mixed samples with a $20 \mu \mathrm{m}$ mesh screen.

Strombidium conicum is well known as a mixotrophic oligotrich that retains functional chloroplasts (Stoecker et al. 1988/ 1989). The plastidic oligotrichs usually show red autofluorescence in epifluorescence microscopy (Laval-Peuto \& Rassoulzadegan 1988). While the red autofluorescence was observed in vegetative $S$. conicum cells in natural Onagawa Bay water, their cysts in sediment were observed free of chloroplasts. Vegetative cells excysted from these cysts in laboratory did not appear red fluorescent. As the present experiment was carried out in a medium without food algae, the excysted cells could not obtain chloroplasts

There are 2 problems in identifying the species of excysted cells. Since the excysted cells in the laboratory are more fragile than naturally occurring cells of the same species, it is difficult to fix them with-
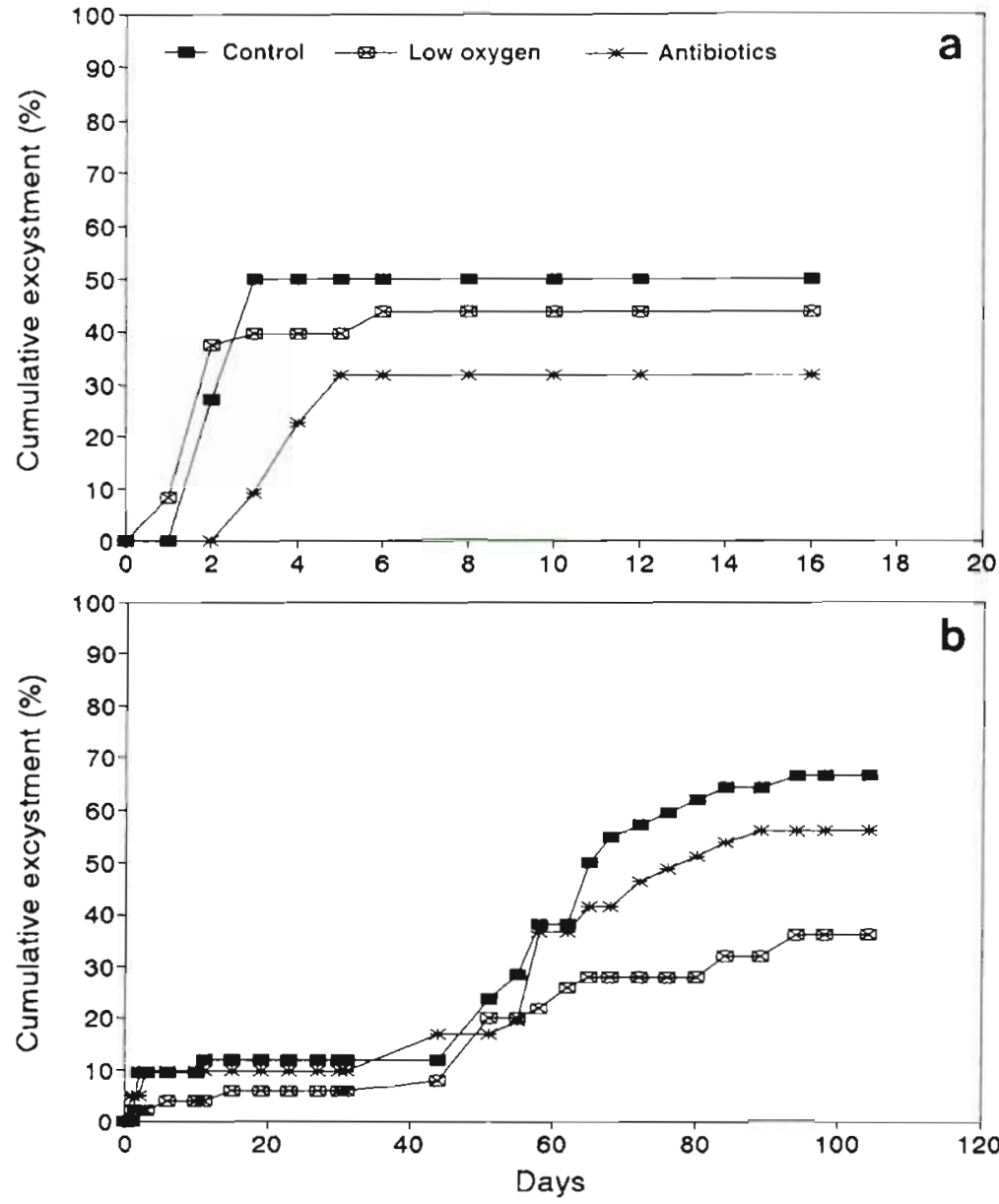

Fig. 15. Strombidium conicum. Effects of oxygen and antibiotics. (a) Cysts sampled in January 1993, cultured at $20^{\circ} \mathrm{C}$ in light; control $(n=48)$, oxygen conc. $9.71 \mathrm{ml} \mathrm{l}^{-1}$, without antibiotics; low oxygen concentration $\left(3.90 \mathrm{ml} \mathrm{l}^{-1}\right)$ $(n=48)$, with antibiotics ( $n=44)$, (b) Cysts sampled in February 1993, cultured at $20^{\circ} \mathrm{C}$ in light; control $(\mathrm{n}=42)$, oxygen conc. $9.74 \mathrm{ml} \mathrm{l}^{-1}$, without antibiotics;

low oxygen concentration $\left(1.87 \mathrm{~mL}^{-1}\right)(\mathrm{n}=50)$, with antibiotics $(\mathrm{n}=41)$

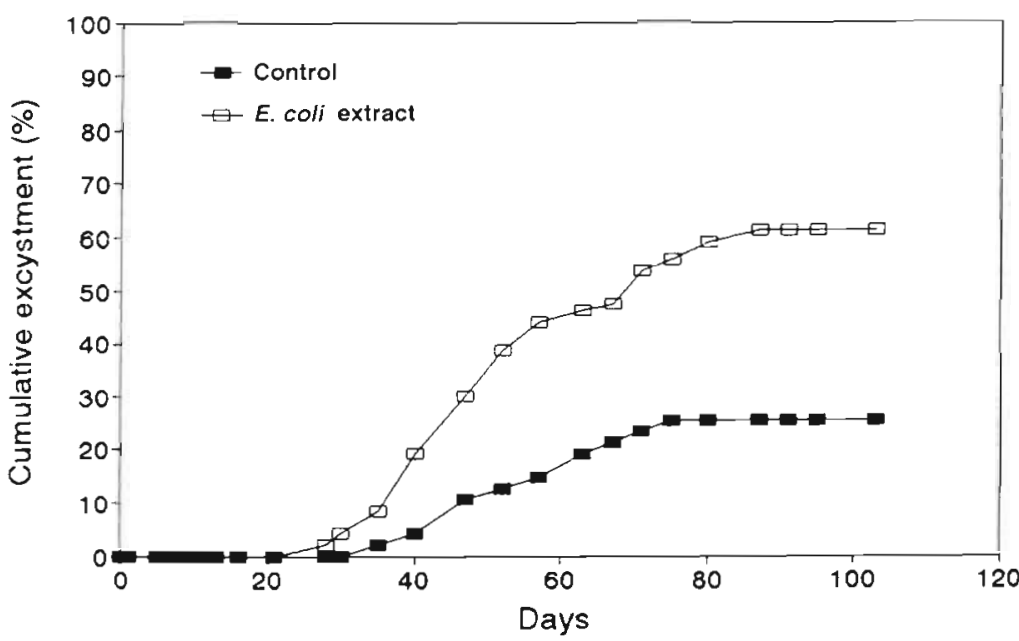

Fig. 16. Strombidium conicum. Effect of bacterial extract. Cysts sampled in June 1993; cultured at $20^{\circ} \mathrm{C}$ in light; control $(n=47)$, with extract of Escherichia coli $(\mathrm{n}=93)$ out morphological damage. The anterior polykinetids are always ruptured by Bouin's fixation, done prior to the protargol staining, although the posterior conical body appears to be relatively intact. Another problem is in the timing of observation. The excysted cells cannot survive more than $1 \mathrm{~d}$ without feeding starved cells lose their swimming activity and finally burst. We must, therefore note that the present identification may be uncertain due to these difficulties.

Excysted cells are smaller than Strombidium conicum described by Montagnes et al. (1988) (71 to $106 \mu \mathrm{m}$ in length and 36 to $61 \mathrm{\mu m}$ in width) Younger cells just excysted from the bottom sediment are smaller and may 
become larger during vegetative life in the water column. Vegetative cells of $S$. conicum collected in this study area were actually larger than the just excysted cells: 62 to $80 \mu \mathrm{m}$ in length and 30 to $42 \mu \mathrm{m}$ in width based on QPS cells $(n=10)$. This may be a reason that the degree of shrinkage of the excysted cells by QPS (ca 10 to $20 \%$ ) observed in this study was small compared to the reported values (30 to $65 \%$ ) (Jerome et al. 1993).

The excystment of Strombidium conicum is influenced by temperature as are tintinnid and dinoflagellate cysts (Anderson 1980, Endo \& Nagata 1984, Kamiyama \& Aizawa 1992). S. conicum usually excysted under warmer conditions, at or above $15^{\circ} \mathrm{C}$, suggesting that increasing temperature triggers the resting cysts to develop into vegetative cells. Light condition was also observed to positively influence excystment, though as a supplementary factor, accelerating excystment in the optimal temperature range.

The excystment rate was observed to be regulated by a prolonged period of storage in a cold and dark place. The spring and fall cysts showed different responses to this treatment. This suggests that the effect of winter depends on the seasonality of cysts, i.e. the excystment of spring cysts is promoted but that of fall cysts is inhibited. Seasonality in response of naturally occurring cysts to variable environmental conditions will be discussed in detail elsewhere when a series of similar experiments is completed.

Debris and bacteria always attach on the outer surface of cysts naturally occurring in the sediment. Therefore, it is almost impossible to culture the cysts under completely sterile conditions. On the other hand, earlier studies have reported that cysts of some ciliates respond positively to addition of organic substances (such as bacteria and/or bacterial extracts) to the culture medium (Butzel \& Horwitz 1965, Beers 1966). Some amino acids and riboflavin have been shown to induce excystment of Schizopyrenus russelli, a soil amoeba (Rastogi et al. 1973). The extract of Escherichia coli, which was found in this study to induce excystment of Strombidium conicum cysts washed twice in sterile sea water, is known to contain various amino acids (cf. Luria 1960). Therefore, it is possible that the amino acids in $E$. coli extracts stimulate $S$. conicum to excyst. On the other hand, antibiotics inhibited the excystment, though whether directly or indirectly
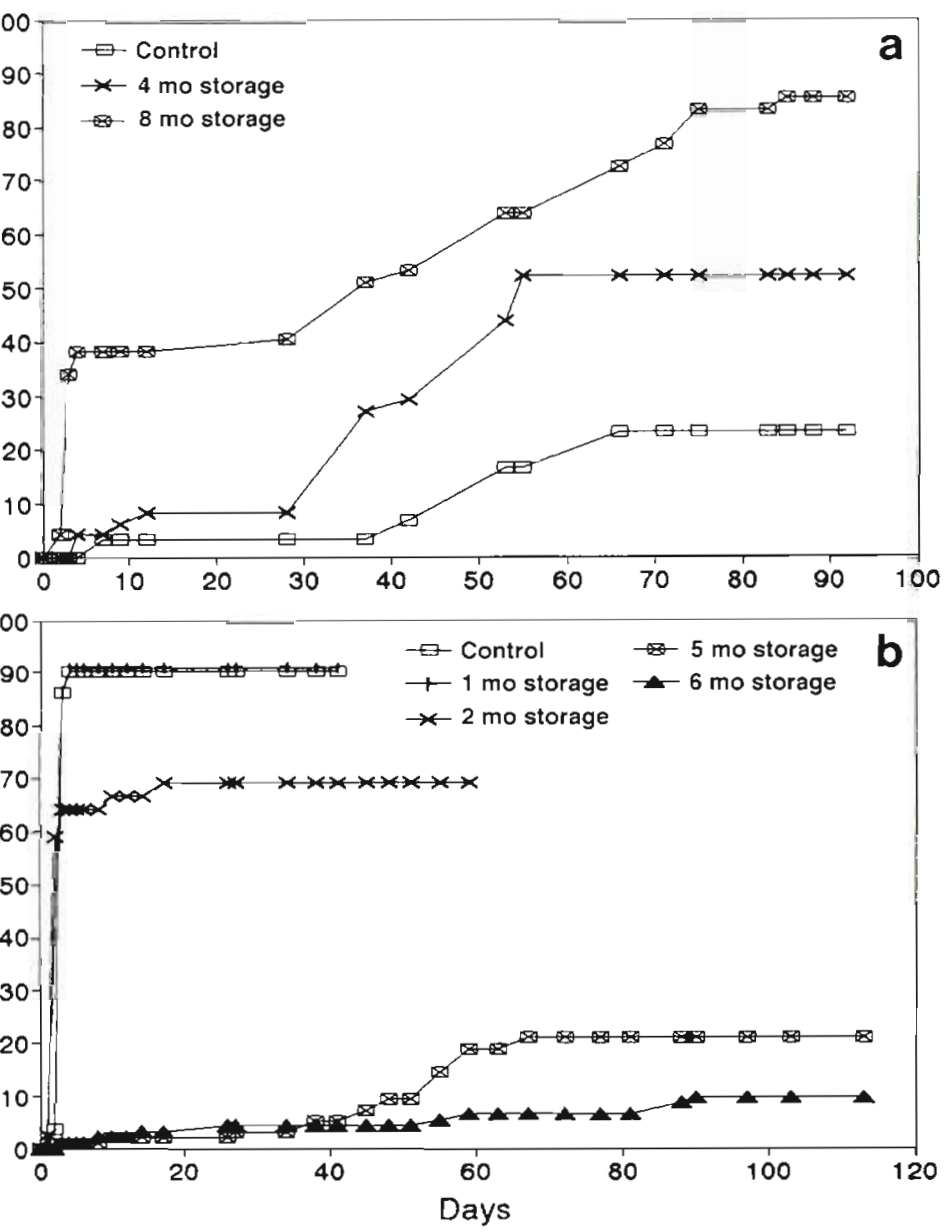

Fig. 17. Strombidium conicum. Effect of treatment in the dark and at low temperatures. (a) Cysts sampled in June 1992 , cultured at $20^{\circ} \mathrm{C}$ in light; control ( $n=30$ ) without treatment, after 4 mo storage $(n=48)$, after 8 mo storage $(n=47)$. (b) Cysts sampled in October 1992 at $20^{\circ} \mathrm{C}$ in light; control $(n=51)$, after 1 mo storage $(n=44)$, after 2 mo storage $(n=39)$, after 5 mo storage $(n=95)$, after 6 mo storage $(n=91)$

is unknown. The antibiotics could inhibit excystment itself and/or inhibit bacterial growth, which in turn would reduce the stimulus to excyst.

Oxygen concentration is another factor affecting recovery rate from resting stages, such as dormant copepod eggs (Uye \& Fleminger 1976, Uye et al. 1979, Lutz et al. 1992) and dinoflagellate cysts (Endo \& Nagata 1984, Anderson \& Keafer 1985). This was also observed in Strombidium conicum: lowered oxygen concentration inhibits excystment, though slightly (Fig. 15a). The water column in Onagawa Bay is vertically stratified in summer and then the oxygen concentration in the bottom layer is lowered (ca $3 \mathrm{ml} \mathrm{l}^{-1}$ ). Therefore, the excystment of oligotrich ciliates on the bottom is likely to be regulated by low oxygen in summer in Onagawa Bay.

In summary, the excystment of Strombidium conicum can be positively controlled by all these environ- 
mental factors such as temperature (preferably 15 to $20^{\circ} \mathrm{C}$ ), light intensity, oxygen concentration, and certain organic substances. Among these, temperature has been recognized to be most important. Further work is needed to understand how the different environmental factors determine the dynamics of encystment and excystment in the natural populations of planktonic aloricate ciliates.

Acknowledgements. We sincerely thank Dr D. H. Lynn, Department of Zoology of the University of Guelph, for his constructive comments on this manuscript and kind correction of our English. Critical reviews by 3 anonymous reviewers were also of great help in later improvement of the manuscript. The collaboration in samplings given by Messrs K. Abe, A. Ishikawa and N. Yamada of the Faculty of Agriculture of the Tohoku University was very much appreciated. This study was partially supported by research grant Nos. 3248105 and 06839003 from the Japan Ministry of Education, Science and Culture.

\section{LITERATURE CITED}

Anderson DM (1980) Effects of temperature conditioning on development and germination of Gonyaulax tamarensis (Dinophyceae) hypnozygotes. J Phycol 16:166-172

Anderson DM. Keafer BA (1985) Dinoflagellate cyst dynamics in coastal and estuarine waters. In: Anderson DM, White AW, Baden DG (eds) Toxic dinoflagellates. Elsevier Science Publishing, New York, p 219-224

Beers CD (1966) The excystment process in the ciliate Nassula ornata Ehrbg. J Protozool 13:79-83

Biernacka I (1952) Studies on the reproduction of some species of the genus Tintinnopsis Stein. Ann Univ Mariae Curie Sklodowska, Sect C 6:211-247

Butzel HM Jr, Horwitz $H$ (1965) Excystment of Didinium nasutum. J Protozool 12:413-416

Corliss JO, Esser SC (1974) Comments on the role of the cyst in the life cycle and survival of free-living protozod. Trans Am Microsc Soc 93.578-593

Endo T, Nagata H (1984) Resting and germination of cysts of Peridinium sp. (Dinophyceae). Bull Plankton Soc Japan $31: 23-33$

Fauré-Fremiet E (1948) Le rythme de marée du Strombidium oculatum Gruber. Bull Biol France-Belgique 82:3-23

Fryxell GA (1983) Survival strategies of the algae. Cambridge University Press, Cambridge

Hoshaw RW, Rosowski JR (1.973) Methods for microscopic algae. In: Stein JR (ed) Handbook of phycological methods. Cambridge University Press, Cambridge,p 53-68

Hughes DE, Wimpenny JWT, Lloyd D (1971) The disintegration of micro-organisms. In: Norris JR, Ribbons DW (eds) Methods in microbiology. Academic Press, London, $p$ $1-54$

Jerome CA, Montagnes DJS, Taylor FJR (1993) The effect of the quantitative protargol stain and Lugol's and Bouin's fixatives on cell size: a more accurate estimate of ciliate species biomass. J Euk Microbiol 40:254-259

Jonsson PR (1994) Tidal rhythm of cyst formation in the rock pool ciliate Strombidium oculatum Gruber (Ciliophora, Oligotrichida): a description of the functional biology and an analysis of the tidal synchronization of encystment $J$ exp mar Biol Ecol 175:77-103

Kamiyama TA, Aizawa Y (1990) Excystment of tintinnid ciliates from marine sediment Bull Plankton Soc Japan 36 $137-139$

Kamiyama TA, Aizawa Y (1992) Effects of temperature and light on tintinnid excystment from marine sediments. Nippon Suisan Gakk 58: 877-884

Laval-Peuto M, Rassoulzadegan F (1988) Autofluorescence of marine planktonic Oligotrichina and other ciliates. Hydrobiologia 159:99-110

Luria SE (1960) The bacterial protoplasm: composition and organization. In: Gunsalus IC, Stanier RY (eds) The bacteria, Vol I, Structure. Academic Press, New York, p 1-34

Lutz RV, Marcus NH, Chanton JP (1992) Effects of oxygen concentrations on the hatching and viability of eggs of marine calanoid copepods. Mar Biol 114:241-247

Matsuoka K, Fukuyo Y, Anderson DM (1989) Methods for modern dinoflagellate cyst studies. In: Okaichi $T$, Anderson DM, Nemoto T (eds) Red tides: biology, environmental science, and toxicology. Elsevier Science Publishing, New York, p 461-479

Montagnes DJS, Lynn DH (1987) A quantitative protargol stain (QPS) for ciliates: method description and test of its quantitative nature. Mar microb Food Webs 2:83-93

Montagnes DJS, Lynn DH, Stoecker DK, Small EB (1988) Taxonomic descriptions of one new species and redescription of four species in the family Strombidiidae (Ciliophora, Oligotrichida). J Protozool 35:189-197

Paranjape MA (1980) Occurrence and significance of resting cysts in a hyaline tintinnid. Helicostomella subulata (Ehre.) Jørgensen. J exp mar Biol Ecol 48:23-33

Rastogi AK, Sagar P, Agarwala SC (1973) Role of riboflavin and certain amino acids in the excystment of Schizopyrenus russelli. J Protozool 20:453-455

Reid PC (1987) Mass encystment of a planktonic oligotrich ciliate. Mar Biol 95:221-230

Reid PC, John AWG (1978) Tintinnid cysts. J mar biol Ass UK 58:551-557

Reid PC, John AWG (1983) Resting cysts in the ciliate class Polyhymenophorea: phylogenetic implications. J Protozool 30:710-713

Sandgren CD (1983) Survival strategies of chrysophycean flagellates: reproduction and the formation of resistant resting cysts. In: Fryxell GA (ed) Survival strategies of the algae Cambridge University Press, Cambridge, p 23-48

Sandgren CD (1989) SEM investigations of statospore (stomatocyst) development in diverse members of the Chrysophyceae and Synurophyceae. Beih Nova Hedwigia 95: $45-69$

Smayda TJ (1958) Biogeographical studies of marine phytoplankton. Oikos 9:158-191

Steidinger KA, Walker LM (1984) Marine plankton life cycle strategies. CRC Press, Boca Raton

Stoecker DK, Silver MW, Michaels AE, Davis LH (1988/1989) Enslavement of algal chloroplasts by four Strombidium spp. (Ciliophora, Oligotrichida). Mar microb Food Webs 3: $79-1.00$

Uye S, Fleminger A (1976) Effects of various environmental factors on egg development of several species of Acartia in southern California. Mar Biol 38:253-262

Uye S, Kasahara S, Onbé T (1979) Calanoid copepod eggs in sea-bottom muds. IV. Effect of some environmental factors on the hatching of resting eggs. Mar Biol 51:151-156 